\title{
Growth and Survival of Larva/Patih Jambal Fish Seed (Pangasius djambal) Maintained Solidly Different Distribution
}

\author{
Jadmiko Darmawan*, Evi Tahapari dan Suharyanto \\ Research Institute for Fish Breeding, Sukamandi, Subang-West Java, Indonesia
}

"Corresponding author: Jadmiko Darmawan, Research Institute for Fish Breeding, Sukamandi Jl. Raya 2 Sukamandi, SubangWest Java 41256, Indonesia. Tel: +620260520500; Fax:+620260520662; Email: micho_jad@yahoo.co.id

Citation: Darmawan J, Suharyanto ETD (2017) Growth and Survival of Larva/Patih Jambal Fish Seed (Pangasius djambal) Maintained Solidly Different Distribution. J Fish Aqua Dev: JFAD-121. DOI:10.29011/JFAD-121/100021

Received Date: 28 August, 2017; Accepted Date: 11 September, 2017; Published Date: 19 September, 2017

\begin{abstract}
Jambal catfish (Pangasius djambal) is a patin of indigenous species of Indonesia that are in great demand by consumers both local and export because it has white meat character and taste better. This study aims to determine the performance of larvae / catfish jambal fish on the character of growth and synthesis are maintained with different density of the spread. Test fish is larvae of catfish jambal result of spawning patin jambal F1 of selection result. Test fish kept in aquarium measuring 60 $\mathrm{cm} \times 30 \mathrm{~cm} \times 40 \mathrm{~cm}$ filled with water media as much as 25 liters. As the stocking density treatment carried out were 30, 60 and 90 head / liter. Maintenance performed for 28 days. The results showed that different density had significant effect on larvae growth of jambal catfish $(p<0.05)$ but did not give a significant effect on larval larvae $(p>0,05)$. The best growth was seen in the treatment of 30 head / liter which yielded the final weight of 1,1657 grams / tail while the lowest growth was seen in the 90 tail / liter treatment which yielded the final weight of $0.7306 \mathrm{gram} / \mathrm{head}$. The synthesis values of treatments $30,60 \mathrm{and} 90 \mathrm{head} / \mathrm{liter}$ were $35.33 \%, 33.33 \%$ and $39.96 \%$, respectively.
\end{abstract}

Keywords: Density of Stocking; Growth and Synthesis; Patin jambal

\section{Introduction}

Catfish is one type of freshwater fish consumption that has important economic value and much in demand by local and international community. The potential of catfish exports to the European market is increasing with the issuance of policies to limit the hunting of cod. Instead, the European community began to turn to white catfish and had a texture similar to cod. Currently $80 \%$ market share of catfish in the world and $25 \%$ market share of catfish in the European market is dominated by Vietnamese patin [1].

According to Gustiano et al. (2003) [2], in the world there are 25 species of catfish and 14 species of which are found in Indonesia. One of the most widely known catfish species and dominates domestic catfish products is Siamese catfish (Pangasianodon hypophthalmus). Siam catfish can grow rapidly in the community because it has many advantages, including easy cultivation process, fast growth, relatively more resistant to disease and environmental stress. However, according to the Directorate General of Aquaculture Fishery (2005) [3], the lack of Siamese catfish is a character of yellowish meat that is less attractive to consumers from developed countries who prefer white fish meat. Indonesia also has several types of white fleshy catfish, one of which is jelly catfish (Pangasius djambal). Jambal catfish are found in the Kahayan river of Palangkaraya, Kapuas Sanggau, Barito Muara Tewe, Batang Hari Jambi, Musi Palembang and Indragiri Rengat (Pouyaud, et al., 1998) [4]. According to Gustiano et al. (2003) [2], jambal catfish has white meat character and is a potential species to be developed as one of the mainstay commodity of aquaculture.

Germination has an important role in the development of catfish jambal, because the availability of seeds continuously in sufficient quantities is one of the key factors in the continuation of the catfish jambal cultivation activities. Although it has been released since 2000 based on the Decree of the Minister of Agriculture No. 265/Kpts/IK.240/5/2000, the development of cat fish cat fish in the community is still very limited. This is due to the lack of information about technical cultivation of catfish jambal, especially aspects of biology such as growth and survival. Bachiel \& Le Cren in Nurlaela et al. (2010) [5], said that one of the most influential aspects in the success of fish farming is the density of stocking of fish that is kept. Hepher \& Pruginin (1981) [6], adding 


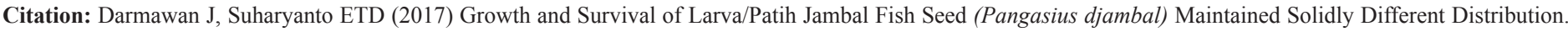
J Fish Aqua Dev: JFAD-121.

that increased density will be followed by a decrease in growth rate and at certain density levels growth will stop. However, the obstacles that still occur in the community is the absence of information about the optimum density level for the maintenance activities of larvae/catfish cat fish jambal. Therefore, a study was conducted to investigate the effect of solid stocking on growth performance and survival rate of larvae of jet fish.

\section{Materials and Methods}

This research was conducted at Testing Laboratory of Patin Hatchery of Fish Breeding Research Institute (BPPI), Sukamandi in February - March 2016. The study was conducted using Completely Randomized Design with three density treatments, ie 30, 60 and 90 head/liter, each repeated as many three times. The tested fish were larvae of artificial spawning result of selected catfish jambal with total length $0,50 \mathrm{~cm}$ and average weight equal to 0.0005 gram. The test fish are maintained using a $60 \times 30 \times 40$ $\mathrm{cm} 3$ aquarium with 25-liter water maintenance volume equipped with aeration installation. The study was conducted for 28 days of maintenance.

The larval catfish larvae begin to feed 36 hours after hatching, because during that time the larvae still have egg yolks that stick to the body and are absorbed for food. Feeding of naupli Artemia sp. Given for 5 days until maintenance day 7. Nauplii Artemia sp. Given every 2 hours on the first day of feeding and every 3 hours on the second day until the fifth day of feeding. Then continued with natural feeding using a silk worm smoothed to day 12 , with feeding frequency every 3 hours. After the larvae were 14 days old, pellet meal was given in the form of powder with 38$40 \%$ protein content, with feeding frequency every 4 hours.

The parameters observed included daily growth rate, daily weight growth, specific weight growth rate and seed survival rate. Water quality parameters such as dissolved oxygen, temperature, $\mathrm{pH}$, and turbidity were observed every 10 days using the Water Quality Checker (WQC) tool, while the nitrite and total ammonia parameters were observed by titrimetry in the laboratory. To know the growth of the daily length is calculated based on the formula [7]:

$$
P L H=\frac{L t-L o}{t}
$$

Where: $\mathrm{PBH}=$ Daily weight gain (grams / day)

$\mathrm{Wt}=$ The average weight of seed end (gram)

$\mathrm{Wo}=$ The mean initial weight of larvae (grams)

$$
\mathrm{T}=\text { Maintenance time }
$$

The growth of daily weight is calculated based on the formula [7]:

$$
P B H=\frac{W t-W o}{t}
$$

Where: $\mathrm{PBH}=$ Daily weight gain (grams / day)

$\mathrm{Wt}=$ The average weight of seed end (gram)

$\mathrm{Wo}=$ The mean initial weight of larvae (grams)

$$
\mathrm{T}=\text { Maintenance time }
$$

Specific seed growth rates of test fish were calculated using the formula [8]:

$$
S G R=\sqrt[t]{\frac{W t}{W o}}-1 \times 100 \%
$$

Where: SGR= Specific Growth Rate (\%)

$\mathrm{T}=$ Maintenance time (day)

$\mathrm{Wt}=$ The final weight of the seed (gram)

$\mathrm{Wo}_{\mathrm{o}}=$ The initial weight of seed stocking (gram)

Seed test seeds were calculated using the formula [7]:

$$
S R=\frac{N t}{N o} \times 100 \%
$$

Where: $\mathrm{SR}=\operatorname{Sintasan}(\%)$

$\mathrm{Nt}=$ Number of seed harvest (tail)

$\mathrm{No}=$ The initial number of seed stock (tail)

Data of weight growth, standard length, total length and seed survival were analyzed using variance analysis. To know the more specific difference between the treatments, the smallest difference was done using the SPSS 19 program.

\section{Results and Discussion}

The results of observation on jetal catfish seeds that were kept with different density showed the final weight, daily weight gain and specific growth rate significantly different between treatments ( $\mathrm{P}$ $<0.05$ ). The result of the research shows that the higher the stocking density the slower the growth of weight will decrease. The best growth profile was demonstrated by treatment of 30 head / $\mathrm{L}$ with daily growth rate of $0.0416 \pm 0.0033 \mathrm{~g} /$ day and a specific growth rate of $31.58 \pm 0.36 \%$. The lowest growth rate was demonstrated by the treatment of 90 heads/L with a daily growth rate of $0.0261 \pm 0.0049 \mathrm{~g} /$ day and a specific growth rate of $29.36 \pm 0.91 \%$, whereas the treatment of 60 heads/L indicated a non- Was significantly different from the treatment of 30 tail / L and 90 head / L (Table 1). 


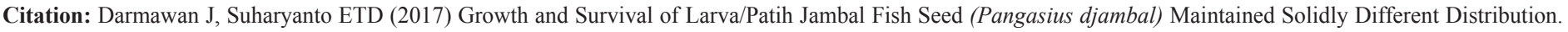
J Fish Aqua Dev: JFAD-121.

\begin{tabular}{|c|c|c|c|c|}
\hline $\begin{array}{l}\text { Treat- } \\
\text { ment }\end{array}$ & $\begin{array}{l}\text { Initial } \\
\text { weight } \\
\text { (gram) }\end{array}$ & $\begin{array}{l}\text { The final } \\
\text { weights } \\
\text { (grams) }\end{array}$ & PBH (g / day) & SGR (\%) \\
\hline A & 0.0005 & 1.1331 & 0.0404 & 31.46 \\
\hline \multirow[t]{3}{*}{$\begin{array}{c}30 \\
\text { tail/L }\end{array}$} & 0.0005 & 1.0945 & 0.0391 & 31.29 \\
\hline & 0.0005 & 1.2694 & 0.0453 & 31.99 \\
\hline & & $1,17 \pm 0,09^{\text {a }}$ & $0,0416 \pm 0,0033^{a}$ & $31,58 \pm 0,36^{\mathrm{a}}$ \\
\hline B & 0.0005 & 0.8097 & 0.0289 & 29.89 \\
\hline \multirow[t]{3}{*}{$\begin{array}{c}60 \\
\text { tail/L }\end{array}$} & 0.0005 & 0.9294 & 0.0332 & 30.53 \\
\hline & 0.0005 & 1.2295 & 0.0439 & 31.84 \\
\hline & & $0,99 \pm 0,22^{\mathrm{ab}}$ & $\begin{array}{c}0,0353 \pm 0,0077 \\
\text { a b }\end{array}$ & $\begin{array}{c}30,75 \pm 0,99 \\
\text { ab }\end{array}$ \\
\hline $\mathrm{C}$ & 0.0005 & 0.5795 & 0.0207 & 28.35 \\
\hline \multirow[t]{3}{*}{$\begin{array}{c}90 \\
\text { tail/L }\end{array}$} & 0.0005 & 0.8481 & 0.0303 & 30.10 \\
\hline & 0.0005 & 0.7643 & 0.0273 & 29.62 \\
\hline & & $0,73 \pm 0,14^{b}$ & $\begin{array}{c}0,0261 \pm 0,0049 \\
\text { b }\end{array}$ & $\begin{array}{c}29,36 \pm 0,91 \\
\mathrm{~b}\end{array}$ \\
\hline
\end{tabular}

Table 1: The performance of jawal catfish seed weight growth on different dispersing density.

Description: The value followed by different superscript letters in the same column shows a significantly different value $(\mathrm{p}<0.05)$.

The observation of jambal catfish seeds which were kept with different density of stock showed the total final length and the daily length increase which was significantly different between treatments $(\mathrm{P}<0.05)$. In line with the rate of growth of weight, the results of a solid study of the distribution of jawal catfish seeds showed that the higher the density of the spreading the longer the growth rate will be slowed down. The highest daily growth rate was shown by the treatment of 30 tail / L of $0.16 \pm 0.01 \mathrm{~cm} /$ day, followed by the treatment of 60 heads / L giving no significant difference with the treatment of 90 heads / $\mathrm{L}$ of $0.14 \pm 0.01$ and $0.13 \pm 0.01 \mathrm{~cm} /$ day (Table 2). Rochdianto in Nurlaela et al. (2010) [5], explains that fish will experience a decrease in growth rate not even grow as a result of space competition. Kadarini et al. (2010) [9] adds that the density of the spreading at some point can lead to competition of space and the seizure of oxygen dissolved in fish, can also cause fish to experience stress, thus inhibiting metabolism and decreasing fish appetite.
The survival rate of jambal catfish seeds on maintenance with a density of stocking of 30, 60 and 90 heads/L gave no significant difference $(\mathrm{P}>0.05)$. Nevertheless, the highest survival rate was achieved by treatment with highest density of $39.96 \%$, followed by treatment of 30 tail/ $\mathrm{L}$ and 60 tail/ $/ \mathrm{L}$ of $35.33 \%$ and $33.33 \%$. According to Budiardi et al. (2007) [10], fish that are kept with too low density tend to be less aggressive in the absence of competition in obtaining space and search for feed.

\begin{tabular}{|c|c|c|c|c|}
\hline $\begin{array}{c}\text { Treat- } \\
\text { ment }\end{array}$ & $\begin{array}{l}\text { Start } \\
\text { length } \\
(\mathrm{cm})\end{array}$ & $\begin{array}{l}\text { End length } \\
\text { (cm) }\end{array}$ & $\begin{array}{c}\text { PLH (cm / } \\
\text { day) }\end{array}$ & Sintasan $(\%)$ \\
\hline A & 0.50 & 5.2 & 0.17 & 54.67 \\
\hline \multirow[t]{3}{*}{$\begin{array}{c}30 \\
\text { tail/L }\end{array}$} & 0.50 & 4.7 & 0.15 & 25.33 \\
\hline & 0.50 & 5.1 & 0.16 & 26.00 \\
\hline & & $4,99 \pm 0,25^{\mathrm{a}}$ & $0,16 \pm 0,01^{\mathrm{a}}$ & $35,33 \pm 15,75^{a}$ \\
\hline B & 0.50 & 4.3 & 0.14 & 50.67 \\
\hline \multirow[t]{3}{*}{$\begin{array}{c}60 \\
\text { tail/L } \\
\end{array}$} & 0.50 & 4.4 & 0.14 & 35.27 \\
\hline & 0.50 & 4.8 & 0.15 & 14.07 \\
\hline & & $4,50 \pm 0,26^{b}$ & $0,14 \pm 0,01^{b}$ & $33,33 \pm 18,38^{a}$ \\
\hline $\mathrm{C}$ & 0.50 & 4.1 & 0.13 & 55.38 \\
\hline \multirow[t]{3}{*}{$\begin{array}{c}90 \\
\text { tail/L } \\
\end{array}$} & 0.50 & 4.4 & 0.14 & 29.78 \\
\hline & 0.50 & 4.2 & 0.13 & 34.71 \\
\hline & & $4,23 \pm 0,15^{b}$ & $0,13 \pm 0,01^{b}$ & $39,96 \pm 13,58^{a}$ \\
\hline
\end{tabular}

Table 2: Horizontal growth and survival rate of jugal catfish seeds at different dispersing densities.

Description: The value followed by different superscript letters in the same column shows a significantly different value $(\mathrm{p}<0.05)$.

The results of observation of water quality parameters during the study showed that the values of temperature range, dissolved oxygen, $\mathrm{pH}$, turbidity, ammonia and nitrite among treatments showed no significant difference. At the parameters of temperature, $\mathrm{pH}$, dissolved oxygen and turbidity are within the optimum range and are still within the tolerant tolerance limits for survival and optimum growth, but on the parameters of ammonia and nitrite have exceeded the optimum limits for growth and survival of jetal catfish seed (Table 3) 
Citation: Darmawan J, Suharyanto ETD (2017) Growth and Survival of Larva/Patih Jambal Fish Seed (Pangasius djambal) Maintained Solidly Different Distribution. J Fish Aqua Dev: JFAD-121.

\begin{tabular}{|c|c|c|c|c|}
\hline \multirow{2}{*}{ Parameter } & \multicolumn{3}{|c|}{ Treatment } & \multirow{2}{*}{$\begin{array}{c}\text { The optimum range } \\
\text { of jelly catfish }\end{array}$} \\
\hline & A (30 tail/L) & B (60 tail/L) & C (90 tail/L) & \\
\hline $\begin{array}{c}\text { Temperature } \\
\left({ }^{\circ} \mathrm{C}\right) \\
\end{array}$ & $29,6-30,3$ & $29,7-30,4$ & $29,7-28,6$ & $26,0-31,0^{*}$ \\
\hline $\mathrm{pH}$ & $6,80-7,05$ & $6,75-7,06$ & $6,76-7,14$ & $6,0-8,9^{*}$ \\
\hline $\begin{array}{c}\text { Dissolved oxygen } \\
(\mathrm{mg} / \mathrm{L})\end{array}$ & $3,57-4,02$ & $3,63-3,91$ & $3,71-3,92$ & $>3,0^{* *}$ \\
\hline Turbiditas (NTU) & $4-15$ & $6-21$ & $5-25$ & - \\
\hline Ammonia (mg/L) & $0,0216-0,5058$ & $0,0216-1,1069$ & $0,0216-3,0317$ & $<0,2^{* *}$ \\
\hline $\begin{array}{l}\text { Nitrite } \\
(\mathrm{mg} / \mathrm{L})\end{array}$ & $0,0185-2,6433$ & $0,0185-2,9594$ & $0,0185-1,3533$ & $<0,1^{* *}$ \\
\hline \multicolumn{5}{|c|}{${ }^{*}$ Legendre et al. (2000) [11]; ${ }^{* *}$ Slembrouck et al. (2003) [12] } \\
\hline
\end{tabular}

Table 3: Water quality of Patine jambal seed maintenance at different dispersing densities.

\section{Conclusion}

Different density had a significant effect on larvae growth of jetal catfish $(\mathrm{p}<0.05)$ but did not have a significant effect on larval larvae $(p>0,05)$. The optimal distribution density for indoor catfish jambal induction by 30 tail/L, but still can be maximized up to 90 head/L with relatively slower growth consequences.

\section{References}

1. Anonymous (2013) Business Development Catfish. Export News. DG PEN/MJL/004/10/2013. Ministry of Trade of RI 3 - 11.

2. Gustiano R, Sudarto, Pouyaud L (2003) How to recognize jelly patin? In: J. Slembrouck, O. Komarudin, Maskur and M. Legendre (eds). Technical Guidelines for Indonesian Patin Fish Hatchery, Pangasius djambal. Institut de la Recherche pour le Development - Ministry of Marine Affairs and Fisheries, Jakarta: 3-14.

3. Directorate General of Aquaculture Fisheries (2005) Priority Policies and Programs of 2006 in the development of aquaculture fishery. Rakernas Ministry of Marine Affairs and Fisheries, Jakarta 31.

4. Pouyoud L, Gustiano R, Legendre M (1998) Phylogenetic relationship among pangasiid catfish species (Siluriformes, Pangasiidae) and new insights on their zoogeography. In: Lagendre, M. And A. Parisele (eds.). The Biological Diversity and Aquaculture of Clariid and Pangasiid Catfishes in South-East Asia. Proceeding of The Mid-Term Workshop of the Catfish Asia Project. Cantho - Vietnam 5: 11-15.

5. Nurlaela IE, Tahapari, Sularto (2010) The growth of cat fish nasutus (Pangasius nasutus) in different stocking density. In: Sudrajat A, Rachmansyah, Hanafi A, Azwar ZI, Imron, Kristanto AH, Chumaidi, Insan I. Prosiding Aquaculture Technology Innovation Forum 2010. Center for Research and Development Aquaculture Jakarta: 31-36.
6. Hepher B, Pruginin Y (1981) Commercial Fish Farming with Special Reference to Fish Culture in Israel. John Willey and Sons, New York: 261.

7. Effendie Ml (1997) Fisheries Biology. Nusatama Library Foundation. Yogyakarta: 163.

8. Castell JD, Tiews K (1980) Report of the EIFAC, IUNS and ICES Working Group on the standardization of methodology in fish nutrition research. Hamburg, Federal Republic of Germany, 21-23 March, 1979. EIFAC Technical Paper: 36: 24.

9. Kadarini TL, Sholichah M, Gladiyakti (2010) The effect of solid stocking on the syntax and growth of silver dollar ornamental fish seed (Metynnis hypsauchen) in the recirculation system. In: Sudrajat A, Rachmansyah, Hanafi A, Azwar ZI, Imron, Kristanto AH, Chumaidi, Insan I. Proceeding of Aquaculture Technology Innovation Forum 2010. Center for Aquaculture Research and Development, Jakarta: 409-416.

10. Budiardi T, Gemawaty N, Wahjuningrum D (2007) Production of neon tetra fish Paracheirodon innesi size $L$ on stocking density 20, 40 and 60 head / liter in recirculation system. Journal of Aquaculture Indonesia 6: 211-215.

11. Legendre M, Slembrouck J, Subagja J (1998) First result on growth and artificial propagation of Pangasius djambal in Indonesia. In the biological divercity clariid and pangasiid catfishes in South East Asia. Procceding of Midterm Workshop of the "Catfish Asia Project", 11-15 May 1998. Cantho. Vietnam: 97-101.

12. Slembrouck J, Subagja J, Sularto (2002) Preliminary study of hybridization of catfish jambal (Pangasius djambal) with siamese patine (Pangasianodon hypophthalmus). Provisional Technical Report. The French Research Institute for Development (IRD). 